\title{
Strategi Komunikasi Melalui Viral Marketing dan Diversifikasi Terhadap Penarikan Pelanggan
}

\author{
Ana Ramadhayanti \\ Universitas Bina Sarana Informatika \\ Jl. Kramat Raya No 98, Senen, Jakarta Pusat \\ e-mail: ana.rdx@bsi.ac.id
}

\begin{tabular}{lll}
\hline Informasi Artikel Diterima: 23-04-2021 Direvisi: 23-05-2021 & Disetujui: 08-06-2021 \\
\hline
\end{tabular}

\begin{abstract}
Abstrak
Penelitian ini terdiri dari tiga variabel yakni Strategi Komunikasi Melalui Viral Marketing (X1), Diversifikasi (X2) dan Penarikan Pelanggan (Y). Adapun tujuan dari penelitian ini adalah untuk mengetahui pengaruh Strategi Komunikasi Melalui Viral Marketing dan Diversifikasi Terhadap Penarikan Pelanggan. Penelitian menggunakan metode penelitian kuantitatif dengan memperoleh data melalui penyebaran kuesioner. Adapun olah data menggunakan sofware SPSS 25. Hasil analisis nilai Sig uji F $0,000>\alpha(0,05)$ yang menunjukkan bahwa variabel bebas Strategi Komunikasi Viral Marketing (X1) dan Diversifikasi (X2) secara simultan berpengaruh terhadap variabel terikat Penarikan Pelanggan (Y). Sementara itu jika dianalisa dengan uji regresi menujukkan Nilai korelasi (R) yang dihasilkan adalah 0,965, sehingga dapat disimpulkan bahwa terdapat hubungan yang sangat erat antara Strategi Komunikasi Viral Marketing (X1) dan Diversifikasi (X2) dengan Penarikan Pelanggan (Y). Dengan melakukan penelitian ini diharapkan dapat menarik produsen lain dalam melakukan Diversifikasi produk.
\end{abstract}

Kata Kunci: Viral Marketing, Diversifikasi, Penarikan Pelangan

\begin{abstract}
This study consists of three variables, namely the Communication Strategy through Viral Marketing (X1), Diversification (X2), and Customer Withdrawal (Y). The purpose of this study is to determine the effect of communication strategies through viral marketing and diversification on customer withdrawal. This research uses quantitative research methods by obtaining data through questionnaires. The data processing uses SPSS 25 software. The results of the analysis of the Sig value of the F test are 0,000, this shows that the Sig test F 0,000> $\alpha(0.05)$ with the F test shows that the independent variables of Viral Marketing Communication Strategy (X1) and Diversification (X2) Simultaneously affects the dependent variable Customer Withdrawal (Y). Meanwhile, if analyzed by regression test, the resulting correlation value $(R)$ is 0.965 , so it can be concluded that there is a very close relationship between Viral Marketing Communication Strategies (X1) and Diversification (X2) with Customer Withdrawal (Y). By conducting this research, it is hoped that it can attract other producers to diversify their products.
\end{abstract}

Keywords: : Viral Marketing, Diversification, Customer Withdrawal

\section{Pendahuluan}

Saat ini pelaku usaha semakin mengalami perkembangan, baik dalam bidang jasa, barang, hingga makan. Seperti yang dilakukan oleh pelaku usaha dibidang industri roti. Diena Bakery merupakan toko roti yang telah berkembang. Perkembangan ini tetunya tidak terlepas dari komunikasi melalui promosi. Salah satu promosi yang dilakukan biasa dalam bentuk strategi viral Marketing. Strategi dengan sistem ini merupakan penyampaian informasi yang dilakukan demgan proses dari mulut kemulut yang dilakukan orangorang. Promosi dengan cara ini merupakan cara yang paling sederhana untuk dilakukan oleh setiap orang tanpa perlu modal dan sederhana. Namun yang harus diperhatikan dalam promosi ini adalah dilihat dari seberapa lama produk tersebut sudah berada dimasyarakat hingga masyarakat dapat mengenal produk yang ditawarkan. Untuk produk yang telah lama digunakan di masyarakat promosi viral marketing dibilang cukup sukses untuk menarik minat hati pelanggan, namun jika produk yang ingin ditawarkan merupakan produk baru maka Diversfikasi produk merupakan langkah yang paling jitu untuk dilakukan. Dengan cara Diversifikasi produk maka para pelaku usaha dapat mengembangkan varian atau produk baru dengan cara mengikutsertakan produk sebelumnya yang laris dipasaran. Namun metode diversifikasi bukalah suatu cara yang mudah dilakukan 
mengingat cara ini menimbulkan resiko yang cukup tinggi terutama dalam sisi finansial. Namun dibalik kekurangan tersebut langkah diversifikasi dianggap sebagai cara yang baik digunakan agar produk baru yang diatawarkan dapat dikenal masyarakat. Saat ini banyak sekali cara diversifikasi dilakukan oleh para pelaku usaha sebagai contoh dibidang makanan dulu orang mengenal Blue Band sebagai margarin namun saat ini Blue Band mengeluarkan produk baru berupa coklat ceres dengan merek yang sama. Contoh lain ada adalah minyak goreng Rose Brand kita kenal sebagai minyak sayur, namun saat ini Rose Brand mengeluarkan produk baru berupa bihun. Dengan melihat dari berbagai contoh tersebut maka dalam studi kasus kali ini penelitian ingin menganalisis Diena Bakery. Pada awalanya Diena Bakery merupakan toko roti yang menjual aneka roti dengan rasa dan varian baru, namun saat ini Diena Bakery telah mengembangkan produk baru berupa selai. Pada dasarnya strategi komunikasi melalui viral marketing dan diversifikasi merupakan langkah yang digunakan untuk menarik pelanggan. Diharapkan dengan komunikasi melalui viral marketing dan diversifikasi Diena Bakery dapat menarikan pelanggan. Penelitian yang dilakukan oleh (Sari, 2019) dengan judul viral marketing: memanfaatkan kekuatan media sosial dalam komunikasi pemasaran. Penelitian kualitatif ini diuraikan berbagai faktor yang dapat mendukung maupun menghambat kesuksesan viral marketing, serta berbagai fasilitas di media sosial yang dapat dimanfaatkan dalam kegiatan pemasaran. Small and Medium Enterprises(SMEs) dan Sony BMG Music merupakan contoh para pelaku usaha yang merasakan langsung dampak terjadinya viral marketing, baik dampak positif maupun negatif. Penelitian lain seperti yang dilakukan oleh Bulan, 2017) dengan judul penelitian Pengaruh Diversifikasi Produk dan Harga terhadap Kepuasan Konsumen pada Juragan Jasmine Langsa menjelaskan bahwa variabel diversifikasi produk dan harga secara simultan berpengaruh signifikan terhadap kepuasan konsumen pada Juragan Jasmine Langsa. Penelitian lain juga dilakukan oleh Kusniadji dengan judul penelitian Strategi Komunikasi Pemasaran Dalam Kegiatan Pemasaran Produk Consumer Goods (Studi Kasus Pada PT Expand Berlian Mulia Di Semarang) hasil dari penelitian ini didapatkan bahwa PT. Expand Berlian Mulia Semarang, dapat dikemukakan dalam membangun komunikasi pemasaran PT. Expand Berlian Mulia menggunakan sarana komunikasi seperti periklanan, personal selling, sales promotion, publisitas dan marketing event.

Untuk mengantisipasi strategi komunikasi pemasaran ke depan, PT. Expand Berlian Mulia juga merancang model komunikasi pemasaran yang kreatif seperti penggunaan Mobil Berjalan dengan
Logo "EXPAND DISTRIBUSI" untuk memposisikan PT. Expand Berlian Mulia sebagai perusahaan distributor Consumer Goods dan Market Leader (Pemimpin Pasar) di Semarang. Penelitiann lainnya yang dilakukan oleh (Gina, 2018) hasil tersebut maka diperoleh bahwa Viral Marketing berpengaruh signifikan terhadap Brand Awareness. Viral marketing dapat menciptakan dan meningkatkan brand awareness terhadap GO-JEK dibenak masyarakat. Sehingga semakin banyak viral marketing, akan semakin meningkat brand awareness yang selanjutnya akan mempengaruhi keputusan masyarakat Banjarmasin untuk menggunakan GO-JEK sebagai transportasi online pilihan mereka. Penelitian serupa juga dilakukan oleh (Candraningrum, 2019), hasil penelitian menyebutkan, lewat uji signifikasi pengaruh parsial, menunjukkan hasil bahwa viral marketing secara individual memiliki pengaruh terhadap keputusan pembelian. Salah satu komponen dalam mendukung berjalannya viral marketing adalah buzz/content, yang merupakan isi, ide dan topik dari video promosi yang disampaikan.

Dengan topik yang menarik dan jelas mengenai informasi dari produk yang dipasarkan oleh Bakso Goreng iONG, membuat konsumen tertarik untuk membeli produk Bakso Goreng Iong. Penelitian (Tarida, 2012) dari strategi diversifikasi produk yang dilakukan oleh produsen kerajinan rotan yakni mengembangkan produksi miliknya sendiri secara internal yakni dengan memproduksi barang-barang yang berbeda terlihat dari jenis produk yang ditawarkan antara lain kursi tamu, kursi makan, sekat ruangan, meja santai, kap lampu, dan tudung saji. Penelitian memperlihatkan bahwa diversifikasi produk berpengaruh positif terhadap penjualan, dimana ada 5 produsen atau 41,66 persen rata-rata omset penjualan dikuasai oleh produsen yang melakukan diversifikasi produk. Hal ini disebabkan oleh para produsen mencari cara agar konsumen dapat memenuhi kebutuhan mereka hanya dengan berbelanja di tempat mereka yakni dengan cara menciptakan beragam jenis produk yang sesuai dengan kebutuhan. Penelitian yang dilakukan (Faizin, dan Hayati, ,2019) menujukkan hasil dari penelitian ini yaitu membuktikan bahwa diversifikasi produk telah memberikan kontribusi yang baik dalam volume penjualan total dan omzet penjualan total sesudah diversifikasi produk dan Presentase produk terjual.

Sementara itu pembaharuan dari penelitian ini adalah peneliti mengkolaborasikan antara variabel strategi komunikasi melalui viral marketing dan diversifikasi terhadap penarikan pelanggan, dimana kolaborasi variabel-variabel tersebut belum pernah diteliti dipenelitian sebelumnya. 
Menurut (Vhl dan Rhee'q, 2012) Arti Viral marketing adalah pemasaran dari mulut ke mulut di mana seseorang mempromosikan sebuah produk atau jasa dengan cara menceritakan kepada orang lain. Misalnya jika seseorang merasa puas dengan pengalaman belanja, kualitas produk atau hasil yang diterimanya, dia akan menceritakannya kepada keluarga, teman-teman atau orang lain yang dianggap membutuhkan. Yang diberitahukan biasanya mengenai tempat dan /atau pemiliki, harga, kualitas atau pelayanan yang diberikan. Ini merupakan bentuk promosi secara tidak langsung yang dilakukan oleh konsumen tanpa bayar atau si pemilik usaha beriklan secara langsung dengan sengaja. Hal ini memberikan keuntungan bagi pengusaha tanpa perlu mengeluarkan biaya apa pun.

Demikian pula sebaliknya bila seseorang tidak puas atau mendapat pelayanan buruk dan produk dengan kualitas buruk, promosi negatif dari mulut ke mulut yang dilakukan si konsumen yang kecewa juga bisa merugikan si pemilik usaha secara langsung maupun tidak langsung.

Di internet, viral marketing dilakukan dengan cara mengirimkan sales leter ke email, forum, situs iklan, akun FB atau jejaring sosial lain, yahoogroups, googlegroups, YouTobe atau posting ke situs/blog miliki orang lain walau isi artikel tidak ada hubungan dengan isi postingan si pelaku VM.

Menurut (Vhl dan Rhee'q, 2012) Ciri-ciri Viral Marketing antara lain:

- Produk dipromosikan melalaui e-mail, jejaring sosial, komunitas atau situs iklan.

- Harga cukup murah karena biaya promosi sangat minim dan tidak menggunakan media iklan konvensional.

- Produk memiliki manfaat dan nilai guna (usable).

- Tidak tersedia di pasar, toko atau supermarket alias bersifat eksklusif.

- $\quad$ Produk dijual langsung hanya oleh satu orang alias tidak melalui perantara dan komisi penjualan di terima langsung oleh si penjual.

- $\quad$ Mirip Direct Selling namun bukan merupakan sistem Direct Selling, Multi Level Marketing atau Sistem Piramid, karena tidak ada sitem upline dan downline, kalaupun ada sangat sedikit perusahaan VM yang melakukannya.

- Tidak ada sitem komisi bertingkat seperti pada MLM atau Sitem Piramid sehingga harga jual menjadi lebih murah kalaupun ada, sedikit perusahaan VM yang melakukan hal itu karena berisiko menyebabkan harga produk menjadi lebih mahal atau komisi penjualan yang diberikan menjadi terlalu kecil.

Keuntungan:

- Promosi melalui internet membuat lebih cepat, hemat waktu dan biaya promosi.

- Bisa disampaikan kepada siapa saja yang memiliki dan bisa memakai internet.

- Harga produk sangat murah karena biaya promosi nol.

- Promosi bisa dilakukan siapa saja yang bisa memakai internet, tidak harus karyawan perusahaan dari produk tersebut.

- Produk yang dijual berfungsi untuk dipakai (used).

- Promosi yang efektif, produk yang sudah dikenal luas dan memiliki reputasi baik cepat mendapat konsumen dan hasil penjualan yang besar.

Kerugian:

- Promosi bisa dianggap spam bila disampaikan pada media tidak cocok.

- Orang yang menerima e-mail promosi VM tidak suka menerimanya dan mennganngap sebagai gangguan.

- Produk yang dijual tidak tersedia secara bebas, hanya melalaui penjualan langsung lewat VM secara eksklusif.

- Masih banyak orang yang menganggap berjual beli di internet sebagai penipuan.

- Tidak semua orang mengerti cara berjualan atau membeli barang di internet.

Menurut (Susilo, 2015) Viral marketing juga menggunakan konsep yang sama seperti ini. Konsep dasarnya adalah membuat marketing (pemasaran) anda bisa menyebar dalam waktu singkat tanpa memerlukan usaha promosi pemasaran yang terllau besar. Media dan obyek yang digunakan oleh pemasaran konsep ini bervariasi. (Suharyadi Suharyadi, Nugroho, Purwanto SK, Faturohman, 2007) Strategi ini merupakan pengembangan produk baru yang masih berhubungan dengan produk lama untuk ditawarkan kepada pasar yang baru juga. Contoh: sebuah perguruan tinggi yang tadinya hanya memberikan pendidikan dengan metode tatap muka di kelas untuk para lulusan-lulusannya baru dari tingkat SMA, sekarang melakukan program kelas karyawan untuk memberi kesempatan bagi orangorang yang telah bekerja dan melakukan pendidikan jarak jauh melalui e-learning atau Internet.

Strategi ini efektif untuk memanfaatkan relung pasar atau kelompok pasar yang selama ini terabaikan atau kurang diperhatikan. Menurut (Griffin, 2005) Definisi customer (pelanggan) memberikan pandangan mendalam yang penting untuk memahami mengapa perusahaan harus menciptakan dan memelihara pelanggan dan bukan hanya menarik pembeli. Definisi ini berasal dari kata custom, yang didefinisikan sebagai "membuat sesautu menjadi kebiasaan atau biasa" dan "mempraktikkan kebiasaan."

Pelanggan adalah seseorang yang menjadi 
terbiasa untuk membeli dari Anda. Kebiasaan itu terbetuk melalui pembelian dan interaksi yang sering selama periode waktu tertentu. Tanpa adanya track record hubungan yang kuat dan pembelian berulang, orang tersebut bukanlah pelanggan Anda, ia adalah pembeli. Pelanggan yang sejati tumbuh seiring dengan waktu.

\section{Metode Penelitian}

Dalam kesempatan ini peneliti melakukan riset dan analisis di toko Diena Bakery yang beralamat di Lagoa Koja Jakarta Utara Kelurahan Lagoa Kecamatan Koja. Motode penelitian yang digunakan adalah penelitian kuantitatif dengan membagikan kuisioner kepada para pelanggan Diena Bakery. Sementara itu variabel yang digunakan dalam penelitian ini adalah terdiri dari tiga variabel yakni dua variabel bebas yang terdiri dari Strategi Komunikasi Melalui Viral Marketing (X1) dan Diversifikasi (X2) serta variabel terikat yakni Penarikan Pelanggan (Y). Penelitian ini menggunakan uji validitas, realibilitas, uji asumsi klasik yang terdiri dari uji normalitas, uji mulikolinearitas, uji heterokedastisitas, uji regresi, uji f. software yang digunakan untuk uji ini adalah software IBM SPSS versi 25.

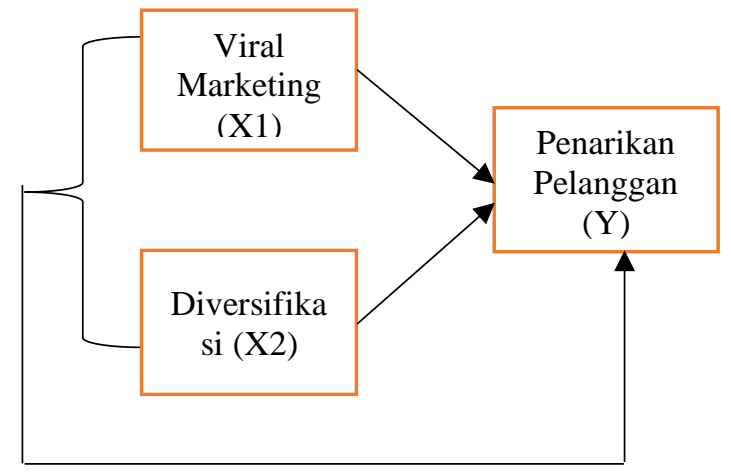

Sumber : Hasil Pengolahan Penulis (2021) Gambar 1 : Kerangka Pemikiran

\section{Hasil dan Pembahasan}

Validitas dan realibilitas merupakan alat ukur agar kesimpulan penelitian memberikan gambaran yang mendekati keadaan sebenarnya dan penelitiannya dapat sepenuhnya dipercaya.

\section{Validitas}

Validitas digunakan untuk mengukur sejauh mana ketepatan dan kecermatan suatu alat ukur dalam melakukan fungsi ukurannya. (Siswanto, 2015) Kriteria pengujian tes validitas:

a. Jika koefisien korelasi product moment melebihi 0.3 (Sugiyono, dalam Siswanto, Victorianus Aries dalam Siswanto, Victorianus Aries 2015)\

b. Jika koefisien korelasi product moment $>\mathrm{r}$ tabel $(\alpha ; n-2) n=$ jumlah sampel. (Santoso dalam Siswanto, Victorianus Aries 2015 )

c. Nilai sign $\leq \alpha \quad(5 \%)$. (Santoso dalam Siswanto, 2015)
Berdasarkan dari hasil perhitungan menujukkan bahwa butir-butir tersebut dinyatakan valid, karena $r$ hitung lebih besar dari pada $r$ tabel. Selain itu dari nilai sig menujukkan bahwa besar nilai $\alpha(5 \%)$.

Tabel 1. Uji Validitas (X1)

\begin{tabular}{|c|c|c|c|c|}
\hline No. & $\begin{array}{l}\text { r hitung } \\
\text { Viral } \\
\text { Marketing } \\
\text { (X1) }\end{array}$ & Sig & $\begin{array}{c}\mathrm{r} \\
\text { tabel }\end{array}$ & $\begin{array}{c}\text { Ketera } \\
\text { ngan }\end{array}$ \\
\hline 1. & 0,831 & $0,000<\alpha(5 \%)$ & 0,098 & Valid \\
\hline 2. & 0,861 & $0,000<\alpha \quad(5 \%)$ & 0,098 & Valid \\
\hline 3. & 0,839 & $0,000<\alpha \quad(5 \%)$ & 0,098 & Valid \\
\hline 4. & 0,611 & $0,000<\alpha \quad(5 \%)$ & 0,098 & Valid \\
\hline 5. & 0,841 & $0,000<\alpha \quad(5 \%)$ & 0,098 & Valid \\
\hline 6. & 0,885 & $0,000<\alpha \quad(5 \%)$ & 0,098 & Valid \\
\hline 7. & 0,710 & $0,000<\alpha \quad(5 \%)$ & 0,098 & Valid \\
\hline 8. & 0,809 & $0,000<\alpha \quad(5 \%)$ & 0,098 & Valid \\
\hline 9. & 0,828 & $0,000<\alpha \quad(5 \%)$ & 0,098 & Valid \\
\hline 10. & 0,916 & $0,000<\alpha \quad(5 \%)$ & 0,098 & Valid \\
\hline 11. & 0,835 & $0,000<\alpha \quad(5 \%)$ & 0,098 & Valid \\
\hline 12. & 0,703 & $0,000<\alpha \quad(5 \%)$ & 0,098 & Valid \\
\hline
\end{tabular}

Sumber: Data yang diolah dengan SPSS 25 (2021)

Tabel 2. Uji Validitas (X2)

\begin{tabular}{ccccc}
\hline No & $\begin{array}{c}\text { r hitung } \\
\text { Diversifika } \\
\text { si (X2) }\end{array}$ & Sig & r tabel & $\begin{array}{c}\text { Keteran } \\
\text { gan }\end{array}$ \\
& & & & \\
\hline 1. & 0,890 & $0,000<\alpha(5 \%)$ & 0,098 & Valid \\
2. & 0,813 & $0,000<\alpha(5 \%)$ & 0,098 & Valid \\
3. & 0,812 & $0,000<\alpha(5 \%)$ & 0,098 & Valid \\
4. & 0,877 & $0,000<\alpha(5 \%)$ & 0,098 & Valid \\
5. & 0,782 & $0,000<\alpha(5 \%)$ & 0,098 & Valid \\
6. & 0,793 & $0,000<\alpha(5 \%)$ & 0,098 & Valid \\
7. & 0,611 & $0,000<\alpha(5 \%)$ & 0,098 & Valid \\
8. & 0,773 & $0,000<\alpha(5 \%)$ & 0,098 & Valid \\
9. & 0,840 & $0,000<\alpha(5 \%)$ & 0,098 & Valid \\
10. & 0,863 & $0,000<\alpha(5 \%)$ & 0,098 & Valid \\
11. & 0,831 & $0,000<\alpha(5 \%)$ & 0,098 & Valid \\
12. & 0,729 & $0,000<\alpha(5 \%)$ & 0,098 & Valid \\
\hline
\end{tabular}

Sumber: Data yang diolah dengan SPSS 25 (2021)

Tabel 3. Uji Validitas (Y)

\begin{tabular}{ccccc}
\hline No. & $\begin{array}{c}\text { r hitung } \\
\text { Penarikan } \\
\text { Pelanggan } \\
(\text { Y) }\end{array}$ & Sig & r tabel & $\begin{array}{c}\text { Ketera } \\
\text { ngan }\end{array}$ \\
& 0,831 & $0,000<\alpha(5 \%)$ & 0,098 & Valid \\
\hline 1. & 0,866 & $0,000<\alpha(5 \%)$ & 0,098 & Valid \\
2. & 0,883 & $0,000<\alpha(5 \%)$ & 0,098 & Valid \\
3. & 0,822 & $0,000<\alpha(5 \%)$ & 0,098 & Valid \\
4. & 0,825 & $0,000<\alpha(5 \%)$ & 0,098 & Valid \\
5. & 0,795 & $0,000<\alpha(5 \%)$ & 0,098 & Valid \\
6. & 0,755 & $0,000<\alpha(5 \%)$ & 0,098 & Valid \\
7. & 0,727 & $0,000<\alpha(5 \%)$ & 0,098 & Valid \\
8. & 0,866 & $0,000<\alpha(5 \%)$ & 0,098 & Valid \\
9. & 0,785 & $0,000<\alpha(5 \%)$ & 0,098 & Valid \\
10. & 0,770 & $0,000<\alpha(5 \%)$ & 0,098 & Valid \\
11. & 0,867 & $0,000<\alpha(5 \%)$ & 0,098 & Valid \\
12. & & & & \\
\hline
\end{tabular}

Sumber: Data yang diolah dengan SPSS 25 (2021) 


\section{Realibilitas}

Realibilitas digunakan untuk mengetahui sejauh mana hasil suatu alat ukur dapat dipercaya. Konsep realibilitas dalam arti realibilitas alat ukur berkaitan dengan kesalahan pengukuran (error of measurement) dan kesalahan sampel (sampling error) yang menunjuk pada inkonsistensi hasil ukur apabila dilakukan ulang pada responden yang berbeda.

Kriteria pengujian tes realibilitas:

a. Menurut Nunally dalam (Siswanto, 2015), data reliabel jika nilai cronbach's alpha $>0.6$.

b. Jika $r$ alpha positif dan $r$ alpha $>r$ tabel $(\alpha ; n-2) n$ jumlah sampel. (Santoso dalam Siswanto, 2015)

c. Menggunakan tabel kriteria indeks koefisien realibilitas.

Tabel 4. Kriteria Indeks

\begin{tabular}{lll}
\hline No & Interval & Kriteria \\
\hline 1 & $<0.200$ & Sangat rendah \\
2 & $0.200-0.399$ & Rendah \\
3 & $0.400-0.599$ & Cukup \\
4 & $0.600-0.799$ & Tinggi \\
5 & $0.800-1.000$ & Sangat tinggi \\
\hline
\end{tabular}

Sumber: Data yang diolah dengan SPSS 25 (2021)

Hasil perhitungan realibilitas menujukkan bahwa nilai nilai cronbach's alpha dari ketiga variabel yakni Strategi Komunikasi Viral Marketing (X1) 0,942, Diversifikasi (X2) 0,942, Penarikan Pelanggan (Y) 0,946, maka dengan demikian dapat disimpulkan bahwa nilai cronbach's alpha >0.6, dan denagn demikian maka semua variabel dinyatakan realiabel.

Tabel 5. Uji Realibilitas (X1)

\section{Case Processing Summary}

\begin{tabular}{llrr}
\hline & & $\mathrm{N}$ & \multicolumn{2}{c}{$\%$} \\
\hline Cases & Valid & 400 & 100,0 \\
& Excluded $^{\mathrm{a}}$ & 0 &, 0 \\
& Total & 400 & 100,0 \\
\hline a. Listwise deletion & based & on all \\
variables in the procedure. &
\end{tabular}

Reliability Statistics

\begin{tabular}{r|r}
\hline \multicolumn{1}{c}{$\begin{array}{c}\text { Cronbach's } \\
\text { Alpha }\end{array}$} & N of Items \\
\hline, 942 & 12 \\
\hline
\end{tabular}

Sumber: Data yang diolah dengan SPSS 25 (2021)
Tabel 6. Uji Realibilitas (X2)

\begin{tabular}{llrr}
\multicolumn{3}{c}{ Case Processing Summary } \\
\hline \multirow{4}{*}{ Cases } & Valid & 400 & \multicolumn{1}{c}{100,0} \\
& Excludeda & 0 &, 0 \\
& Total & 400 & 100,0 \\
\hline
\end{tabular}

a. Listwise deletion based on all variables in the procedure.

\begin{tabular}{rr}
\multicolumn{2}{c}{ Reliability Statistics } \\
\hline $\begin{array}{c}\text { Cronbach's } \\
\text { Alpha }\end{array}$ & N of Items \\
\hline, 942 & 12 \\
\hline
\end{tabular}

Tabel 7. Uji Realibilitas (Y)

Case Processing Summary

\begin{tabular}{llr|r}
\hline & & $\mathrm{N}$ & \multicolumn{1}{c}{$\%$} \\
\hline Cases & Valid & 400 & 100,0 \\
\cline { 2 - 4 } & Excluded & 0 &, 0 \\
\cline { 2 - 4 } & Total & 400 & 100,0 \\
\hline
\end{tabular}

a. Listwise deletion based on all variables in the procedure.

\begin{tabular}{r|r}
\multicolumn{2}{c}{ Reliability Statistics } \\
\hline $\begin{array}{c}\text { Cronbach's } \\
\text { Alpha }\end{array}$ & N of Items \\
\hline, 946 & 12 \\
\hline
\end{tabular}

Sumber: $\overline{\text { Data yang diolah dengan SPSS } 25}$ (2021)

\section{Uji Asumsi Klasik}

Multikolineritas (VIF)

Menurut (Sujarwweni dan Utami, 2019) Uji multikolineritas diperlukan untuk mengetahui ada tidaknya variabel independen yang memiliki kemiripan antarvariabel independen dalam suatu model. Kemiripan antar variabel independen akan mengakibatkan korelasi yang sangat kuat. Selain itu uji ini juga untuk menghindari kebiasaan dalam proses pengambilan keputusan mengenai pengaruh pada uji paersial masing-masing variabel indepen terhadap variabel dependen. Jika VIF yang dihasilkan di antara 1-10, maka tidak terjadi multikolinieratas.

Hasil perhitungan dengan menggunakan SPSS menujukkan bahwa nilai VIF sebesar 7, 239, angka ini menjukkan bahwa VIF lebih kecil dari 10, maka dapat disimpulkan tidak terjadi mulikolinearitas. 
Tabel 8. Uji Multikolineritas (VIF)

\begin{tabular}{|c|c|c|c|c|c|c|c|}
\hline \multicolumn{8}{|c|}{ Coefficients $^{a}$} \\
\hline & \multicolumn{2}{|c|}{$\begin{array}{l}\text { Unstandardi } \\
\text { zed } \\
\text { Coefficients }\end{array}$} & $\begin{array}{l}\text { Standa } \\
\text { rdized } \\
\text { Coeffi } \\
\text { cients } \\
\end{array}$ & & & \multicolumn{2}{|c|}{$\begin{array}{l}\text { Collinea } \\
\text { rity } \\
\text { Statistics }\end{array}$} \\
\hline Model & $\mathrm{B}$ & $\begin{array}{l}\text { Std. } \\
\text { Error }\end{array}$ & Beta & $\mathrm{t}$ & Sig. & $\begin{array}{l}\text { To } \\
\text { ler } \\
\text { an } \\
\text { ce }\end{array}$ & VIF \\
\hline (Constant) & $\begin{array}{r}- \\
1,01 \\
5\end{array}$ & ,783 & & $\begin{array}{r}- \\
1,2 \\
96\end{array}$ & ,196 & & \\
\hline $\begin{array}{l}\text { Strategi } \\
\text { Komunika } \\
\text { si Viral } \\
\text { Marketing } \\
\text { (X1) }\end{array}$ & ,263 & 041 & ,228 & $\begin{array}{r}6,4 \\
60\end{array}$ & ,000 & $\begin{array}{r}, 1 \\
38\end{array}$ & $\begin{array}{r}7,2 \\
39\end{array}$ \\
\hline $\begin{array}{l}\text { Diversifik } \\
\text { asi }(\mathrm{X} 2)\end{array}$ & ,745 & 035 & ,750 & $\begin{array}{r}21 \\
219\end{array}$ &, 000 & $\begin{array}{r}, 1 \\
38\end{array}$ & $\begin{array}{r}7,2 \\
39\end{array}$ \\
\hline
\end{tabular}

a. Dependent Variable: Penarikan Pelanggan (y)

Sumber: Data yang diolah dengan SPSS 25 (2021)

\section{Heteroskedastisitas (scatterplot)}

Menurut (Sujarwweni dan Utami, 2019) menguji terjadinya perbedaan varian residual suatu periode pengamatan ke periode pengamatan yang lain. Cara memprediski ada tidaknya heteroskedastisitas pada suatu model dapat menggunakan cara:

Gambar Scatterplot

Kriteria regresi yang tidak terjadi heteroskedastisitas jika:

a. Titik-titik data menyebar di atas dan di bawah atau disekitar angka 0.

b. Titik-titik data tidak mengumpul hanya di atas atau di bawah saja.

c. Penyebaran titik-titik data tidak boleh membentuk pola bergelombang melebar kemudian menyempit dan melebar kembali.

d. Penyebaran titik-titik data tidak berpola.

Analisa berdasarkan hasil perhitungan menujukkan bahwa nilai Titik-titik data menyebar di atas dan di bawah atau di sekitar 0, Titik-titik data tidak mengumpul hanya di atas atau di bawah saja.

Penyebaran titik-titik data tidak membentuk pola bergelombang melebar kemudian menyempit dan melebar kembali. Penyebaran titik-titik data tidak berpola maka dengan demikian dapat disimpulkan tidak terjadi heteroskedastisitas

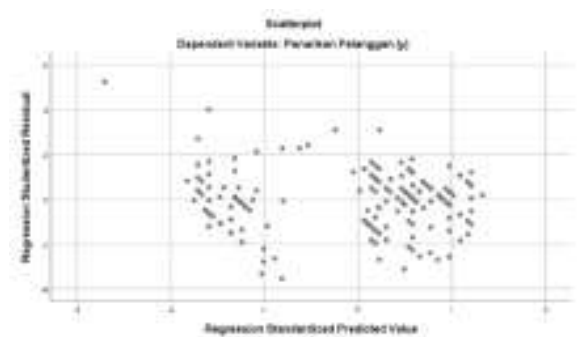

Gambar 2. Uji Heteroskedastisitas (scatterplot)

\section{Uji Normalitas}

Uji normalitas adalah untuk melihat apakah nilai residula terdistribusi normal atau tidak. Model regresi yang baik adalah memliki nilai residual yang terdistribusi normal. Menurut Ghozali dalam (Purnomo, 2019) untuk medeteksi normalitas data dapat juga dengan uji Kolmogrof Smirnov per variabel, atau Kolmogrof Smirnov dilihat dari nilai residual. Dikatakan normal bila nilai residual yang dihasilkan di atas nilai signifikansi yang ditetapkan (Purnomo, 2019).

Hasil perhitungan menujukkan bahwa data berdistribusi normal, hal ini terlihat dari gambar histogram yang menjukkan bahwa data berdistribusi normal.
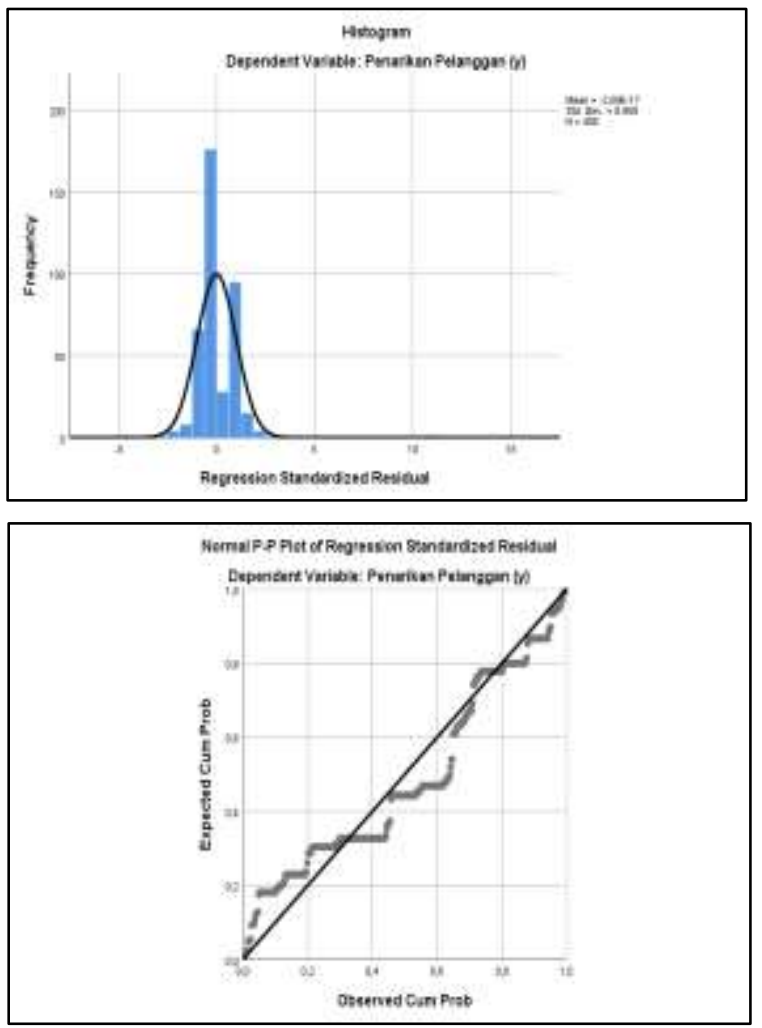

Gambar 3. Uji Scatterplot

Uji Regresi

Tabel 9. Uji Regresi

Model Summary ${ }^{b}$

Std.

R Adjusted Error of

\begin{tabular}{lcrrrr} 
Mo & & Squar & $\mathrm{R}$ & the & Durbin- \\
del & $\mathrm{R}$ & $\mathrm{e}$ & Square & Estimate & Watson \\
\hline 1 &, $965^{\mathrm{a}}$ &, 932 &, 931 & 1,732 & 2,157 \\
\hline
\end{tabular}

a. Predictors: (Constant), Viral Marketing (X2),

Strategi Diversifikasi (X1)

b. Dependent Variable: Penarikan Pelanggan (y) 
Nilai korelasi (R) yang dihasilkan adalah 0,965, sehingga dapat disimpulkan bahwa terdapat hubungan yang sangat erat antara Strategi Komunikasi Viral Marketing (X1) dan Diversifikasi (X2) dengan Penarikan Pelanggan (Y) (Aqil dan Efendi, 2015).

Nilai R-square atau koefisien determinasi Menjelaskan makna bahwa Strategi Komunikasi Viral Marketing (X1) dan Diversifikasi (X2) secara simultan berpengaruh terhadap Penarikan Pelanggan (Y) sebesar 0,932 atau sama dengan 93,2\%.. Sementara itu sisanya $100-93,2 .=6,8 \%$ dipengaruhi oleh variabel lain diluar penelitian.

\section{Uji F}

Hipotesis dalam pengujian pengaruh variabel bebas bersama-sama terhadap variabel terikat adalah sebagai berikut (Prihanti, 2016) :

H 0 : B0 -B4 = 0, tidak terdapat pengaruh variabel bebas terhadap variabel terikat secara bersama-sama $\mathrm{H} 1: \mathrm{Bi} \neq 0$, paling tidak terdapat satu pengaruh varaibel bebas bebas terhadap varaibel terikat seacara bersama-sama

Pengambilan keputusan berdasarkan signifikansi:

Sig uji $\mathrm{F}<\alpha$, maka $\mathrm{H} 0$ ditolak, berarti varaibel bebas secara simultan berpengaruh terhadap variabel terikat.

Sig uji $\mathrm{F}>\alpha$ maka H0 diterima, bearrti varaiabel bebas secara simultan tidak berpengaruh terhadap varaibel terikat.

Tabel 10. Uji F

ANOVA $^{a}$

\begin{tabular}{rrrrrrr}
\hline & & $\begin{array}{c}\text { Sum of } \\
\text { Square }\end{array}$ & & & & \\
Mean & & \\
Model & \multicolumn{1}{c}{ s } & df & Square & \multicolumn{1}{c}{ F } & Sig. \\
\hline 1 & Regre & 14853, & 1 & 14853, & 2327 &, 000 \\
& ssion & 825 & & 825 &, 056 & b \\
& Resid & 2540,4 & 398 & 6,383 & & \\
ual & 72 & & & & \\
& Total & 17394, & 399 & & & \\
& 297 & & & & \\
\hline
\end{tabular}

a. Dependent Variable: Penarikan Pelanggan (y)

b. Predictors: (Constant), Strategi Diversifikasi (X1)

Sumber: Data yang diolah dengan SPSS 25 (2021)

Berdasarkan hasil dari perhitungan menunjukkan bahwa nilai Sig uji F sebesar 0,000 hal ini menunjukkan bahwa Sig uji F $0,000>\alpha(0,05)$. Dengan demikian maka H0 ditolak, berarti variabel bebas Strategi Komunikasi Viral Marketing (X1) dan Diversifikasi (X2) secara simultan berpengaruh terhadap variabel terikat Penarikan Pelanggan (Y).

\section{Uji Parsial}

Dasar Pengambilan Keputusan Uji t Parsial dalam Analisis Regresi untuk melakukan uji hipitesis penelitian di atas, maka harus mengetahui dasar pengambilan keputusan dalam uji t parsial. Dalam hal ini ada dua acuan yang dapat dipakai sebagai dasar pengambilan keputusan, pertama dalam melihat nilai signifikansi (Sig), dan dua membandingkan antara nilai t hitung dengan $\mathrm{t}$ tabel.

Berdasarkan Nilai Signifikansi (Sig.)

Jika nilai Signifikansi (Sig). < probabilitas 0.05 maka ada pengaruh variabel bebas $(\mathrm{X})$ terhadap variabel terikat (Y) atau hipotesis diterima.

Jika nilai Signifikansi (Sig). > probabi;itas 0,05 maka tidak ada pengaruh variabel bebas (x) terhadap variabel terikat (Y) atau hipotesis ditolak.

Berdasarkan perbandingan Nilai t hitung dengan $t$ tabel

Jika nilai thitung $>\mathrm{t}$ tabel maka ada pengaruh varibel bebas $(\mathrm{x})$ terhadap variabel terikat $(\mathrm{Y})$ atau hipotesis diterima

Jika nilai $\mathrm{t}$ hitung < t tabel maka tidaka ada pengaruh variabel bebas (X) terhadap variabel terikat (Y) atau hipotesis ditolak.

\section{Uji t Parsial Strategi Diversifikasi (X1)}

Uji t pertama dilakukan untuk mengetahui apakah ada pengaruh Strategi Diversifikasi (X1) terhadap Penarikan Pelanggan (Y).

Berdasarkan Nilai Signifikansi (Sig)

Berdasarkan tabel output SPSS "Coefficients" diketahui nilai Signifikansi (Sig) variabel Strategi Diversifikasi (X1) sebesar 0.000. Karena nilai Sig. $0,000<$ probabilitas 0,05 , maka dapat disimpulkan bahwa $\mathrm{H} 1$ atau hipotesis pertama diterima. Artinya ada pengaruh Strategi Diversifikasi (X1) terhadap Penarikan Pelanggan (Y).

Perbandingan Nilai $\mathrm{t}$ hutung dengan $\mathrm{t}$ tabel (uji $\mathrm{t}$ pertama)

Berdasarkan output SPSS didapatkan nilai t hitung $\mathrm{X} 1$ sebesar 6,640. Karena nilai thitung 6,640 > t tabel 1,966, maka dapat disimpulkan bahwa $\mathrm{H} 1$ atau hipotesis pertama diterima. Artinya ada pengaruh Strategi Diversifikasi (X1) terhadap Penarikan Pelanggan (Y).

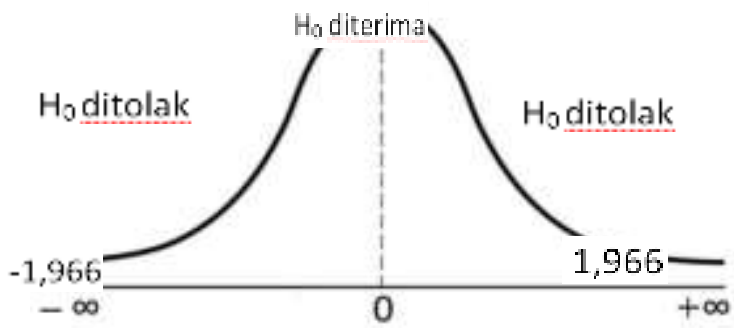

Gambar 4. Distribusi Normal Uji t Strategi Diversifikasi (X1) 


\section{Uji t Parsial Viral Marketing (X2)}

Uji t pertama dilakukan untuk mengetahui apakah ada pengaruh Viral Marketing (X2) terhadap Penarikan Pelanggan (Y).

Berdasarkan Nilai Signifikansi (Sig)

Berdasarkan tabel output SPSS "Coefficients" diketahui nilai Signifikansi (Sig) variabel Strategi Diversifikasi (X1) sebesar 0.000. Karena nilai Sig. $0,000<$ probabilitas 0,05 , maka dapat disimpulkan bahwa $\mathrm{H} 2$ atau hipotesis kedua diterima. Artinya ada pengaruh Viral Marketing (X2) terhadap Penarikan Pelanggan (Y).

Perbandingan Nilai $\mathrm{t}$ hutung dengan $\mathrm{t}$ tabel (uji $\mathrm{t}$ pertama)

Berdasarkan output SPSS didapatkan nilai t hitung X2 sebesar 21,219. Karena nilai t hitung 21,219. > t tabel 1,966, maka dapat disimpulkan bahwa $\mathrm{H} 2$ atau hipotesis kedua diterima. Artinya ada pengaruh Viral Marketing (X2) terhadap Penarikan Pelanggan (Y).

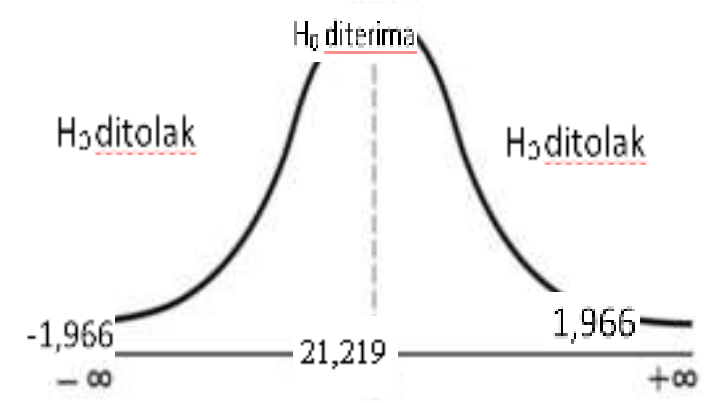

Gambar 5. Distribusi Normal Uji t Viral Marketing (X2)

\section{Kesimpulan}

Berdasarkan hasil penelitian maka dapat diambil kesimpulan sebagai berikut: Uji $F$ menujukkan bahwa variabel bebas yakni Strategi Komunikasi Viral Marketing (X1) dan Diversifikasi (X2) secara simultan berpengaruh terhadap variabel terikat Penarikan Pelanggan (Y) hal ini dilihat dari nilai Sig uji F $0,000>\alpha(0,05)$. Sementara itu jika diuji secara regresi Nilai Rsquare atau koefisien determinasi sebesar 0,932 Hal ini menujukkan bahwa kemampuan sebesar dan masih terdapat $100-93,2 .=6,8$ variabel lain yang mempengaruhi hasil.

\section{Referensi}

Aqil, Muhammas dan Efendi, R. (2015). Aplikasi SPSS dan SAS Untuk Perancangan Percobaan. Yogyakarta: Absolute Media

Bulan, Tengku Putri Lindung. 2017. Pengaruh Diversifikasi Produk dan Harga terhadap Kepuasan Konsumen pada Juragan Jasmine
Langsa. JURNAL MANAJEMEN DAN KEUANGAN, VOL. 6, NO. 1, MEI 2017. ISSN 2252-844X.

Candraningrum, Velia, Diah Ayu. 2019. Pengaruh Viral Marketing Video Promosi Instagram terhadap Keputusan Pembelian Konsumen Bakso Goreng iONG. EISSN 2598-0777. Prologia Vol. 3, No. 2, Desember2019, Hal 358-364.

Faizin, Muhammad, Azizah, Nur dan Hayati, Fitri. 2019. Diversifikasi Produk Terhadap Penjualan Lampu Romantis Batu Akik (Lapis Batik) Purbalingga. Jurnal Terapan Ilmu Manajemen Dan Bisnis. Vol.2 No.1.

Griffin, J. (2005). Customer Loyalty Menumbuhkan \& Mempertahankan Kesetiaan Pelanggan. Jakarta: Erlangga.

Gina, Alfil. 2018. Pengaruh Viral Marketing terhadap Brand Awareness dan Kepercayaan Konsumen serta Dampaknya terhadap Keputusan Penggunaan Jasa Transportasi GO-JEK di Banjarmasin. Jurnal Ilmu Manajemen IndonesiaVol. 1. No.1. Maret2018Hal: 1-13.

Kusniadji, Suherman. 2017. Strategi Komunikasi Pemasaran Dalam Kegiatan Pemasaran Produk Consumer Goods(Studi Kasus Pada PT Expand Berlian Mulia Di Semarang) . Jurnal Komunikasi ISSN 2085-1979, EISSN 772528 202009 Vol. 8, No. 1, Juli 2016, Hal 83 - 98.

Prihanti, G. S. (2016). Pengantar Biostatistik. Malang: Universitas Muhammadiyah Malang.

Purnomo, A. K. (2019). Pengolahan Riset Ekonomi Jadi Mudah Dengan IBM SPSS. Surabaya: CV. Jakad Publishing.

Siswanto, V. A. (2015). Belajar Sendiri SPSS 22. Yogyakarta: CV. ANDI OFFSET.

Suharyadi, Nugroho, Arissetyanto , Purwanto SK, Faturohman, Maman. (2007). Kewirausahaan Membangun Usaha Sukses Sejak Usia Muda. Jakarta: Salemba Empat.

Sujarwweni, V. Wiratna dan Utami, L. R. (2019). The Master Book Of SPSS Pintar Mengolah Data Statistik untuk Segala Keperluan Secara Otodidak. Yogyakarta: Anak Hebat Indonesia.

Susilo, Joko. (2015). Sistem Mesin Uang Otomatis. Amerika Serikat: ForBis Corp.

Sari, Ratna Kartika. 2019. Viral Marketing : Memanfaatkan Kekuatan Media Sosial Dalam Komunikasi Pemasaran. Cermin : Jurnal Penelitian. Volume 3 , Nomor 2, Desember 2019.

Tarida, Yuni. 2012. Strategi Diferensiasi Produk, Diversifikasi Produk, Harga Jual Dan Kaitannya Terhadap Penjualan Pada Industri Kerajinan Rotan Di Kota Palembang. Jurnal Ekonomi Pembangunan, Desember 2012. Volume 10, No.2 hal: 124-142.

Vhl dan Rhee'q. (2012). Cara Gampang Cari Duit di Internet. Jakarta: PT. Gramedia Pustaka Utama. 